\title{
Content and source analysis of newspaper items about Māori issues: Silencing the 'natives' in Aotearoa?
}

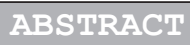

This article reports on a content analysis of newspaper items from Aotearoa/ New Zealand about Māori issues, focusing on level of coverage, topics and sources. Results from analysis of a representative sample of news items from six months over 2007-2008 were compared with two previous pilot studies in 2004 and early 2007. The study found that the mass media covered Māori stories at very low rates, worked a narrow range of topics and prioritised Pākehā sources over Māori, even in articles specifically about Māori issues. The authors sketch an indigenous theory of media news processes and relate these findings to already published thematic and discourse analyses of the materials from the same database to illustrate the roles of mass media coverage in the dynamics of national life in Aotearoa.

Keywords: Aotearoa, content analysis, hegemonic discourse, journalism, Māori, mass media, Newspapers, New Zealand, Pākehā, representations.

JENNY RANKINE (University of Auckland), ANGELA MOEWAKA BARNES, TIM MCCREANOR, RAY NAIRN (Te Rōpū Whāriki, Massey University), ANNA-LYSE MCMANUS, SUE ABEL (University of Auckland), BELINDA BORELL (Te Rōpū Whäriki) and AMANDA GREGORY

Māori have long aspired to an equal voice in the media allowing expression and accurate representation. (Haami, 2008, p. 24)

7 HIS SUCCINCT comment is founded upon powerful indigenous Māori traditions of praxis in Aotearoa that have sustained a resistance to unwelcome and disastrous colonial appropriation of their lands, 
exploitation of their resources and disruption of their cultural, economic, social and spiritual ways of life (Durie, 2003; Smith, 1999; RJ Walker, 1990a). Mass media have been a key tool of colonisation since before the earliest systematic European settlement (Ballara, 1986; Colvin, 2010; RJ Walker, 1990a) and, the epigraph suggests, remain so in the contemporary era.

Here we report from a three-year research project that produced quantitative and qualitative measures of representations of Māori in mass media, ${ }^{1}$ and assessed impacts of news media discourses on Māori wellbeing and Māori/ Pākehā relations. We frame the analysis within an emerging indigenous theory of mass media news practices (A. Moewaka Barnes et al., 2012) and kaupapa Māori research methods. ${ }^{2}$ We combine content analyses of newspaper data with insights from thematic and discourse analyses to critique established newspaper practices.

\section{Māori in Aotearoa}

Since first contact Māori as tangata whenua, ${ }^{3}$ have struggled to maintain their self-determination and enhance their economic, cultural and identity development, despite the impacts of colonisation (Smith, 1999; RJ Walker, 1990a). Te Tiriti o Waitangi (Treaty of Waitangi), agreed between Māori leaders and the British Crown in 1840, guaranteed Māori sovereignty and was a cornerstone of these sustained efforts. Eventually this struggle resulted in the establishment of the Waitangi Tribunal in 1975 to consider breaches of te Tiriti, and advise government on redress (Waitangi Tribunal, 2011). While some important settlements have been achieved, ongoing depredations against Māori assets, culture and aspirations by the settler state continue (such as the state theft of unalienated Māori marine estate in the Foreshore and Seabed Act 2004).

Māori were 14.9 percent of the New Zealand population in the 2013 Census (Statistics New Zealand, 2014) and are disproportionately represented in measures of disadvantage (Ministry of Social Development, 2010; Reid \& Robson, 2007). Pākehā, on the other hand, show more positive outcomes in education, work, income, health and experience less poverty, crime, discrimination (Robson \& Harris, 2007) and unemployment (Ministry of Social Development, 2010). Pākehā are twice as likely to be in the highest quintile of household incomes, and far less likely to live in poverty or in households on benefits (Robson \& Harris, 2007). On most health problems, Pākehā age- 
standardised rates are significantly lower than those for Māori, reflected in an expected eight more years of life (Statistics New Zealand, 2008).

This disparate picture is lightened by recent advances in certain areas including media. The formation of the Māori Party in 2004 changed the political landscape, promoting Māori aspirations and becoming part of a governing coalition in 2008. Treaty settlements, including resource claims around fisheries and broadcasting spectra, have transferred land, money and resources (Office of Treaty Settlements, 2013), although for land these amount to less than one percent of what was taken (Mutu, 2011). Development of these resources has increased the size of the Māori economy (Te Puni Kokiri, 2011).

After continuous Māori lobbying and a Waitangi Tribunal claim, Māori broadcasting was established to help regenerate the Māori language and culture; 21 iwi (tribal) radio stations were founded between 1989 and 1994 (Te Mangai Paho, 2011). The Māori Television Service began broadcasting in 2004, and has two channels, one entirely in te reo Māori (Māori Television, 2010). However, there have been no large circulation Māori newspapers in this country since the late 1800 s.

\section{Theorising indigeneous mediaspheres}

The major conceptual drive underlying this research project is indigenous. This is congruent with the suggestion by Connell (2007) and others that theory generated by the 'metropole' (US and Western Europe) cannot be as relevant in accounting for power, social dynamics and inequity within colonised indigenous settings. In Aotearoa, kaupapa Māori approaches based on Māori philosophies and aspirations (H. Moewaka Barnes, 2000; Pihama, Cram, \& Walker, 2002; Smith, 1999) exemplify what Connell refers to as 'Southern theory' and provide a powerful platform for development. An example is the $\mathrm{PhD}$ thesis by A. Moewaka Barnes (2011) which develops kaupapa Māori theory and frameworks for examining indigenous film.

This framework challenges dominant ways of seeing, interpreting and valuing, embedded in news stories, through questions such as:

- Whose voice is heard?

- Whose languages are used?

- Whose worldviews are centered?

- Does the coverage challenge hegemonic colonial discourses?

- Are Māori equitably visible?

- How are Māori experiences, in their diversity, represented? 
Here we transfer elements of this framework into the realm of news coverage to understand our findings We view mass media as a central institution of colonial power, tightly linked to hegemonic discourse and fundamental to the 'colonisation of the mind' (Ngugi, 1986) - the ultimate goal in the disempowerment of indigenous peoples.

The colonial media frame in Aotearoa doubly neglects Māori contributions to national life while highlighting problematic or challenging aspects. Although Māori are more seriously affected, this positoning of indigenous people also has consequences for colonisers in identity, wellbeing and social cohesion (Gregory et al., 2011; Nairn et al., 2011).

\section{Mass media representations of the 'Other'}

Indigenous and minority communities have long been constructed in the mass media as threatening and needing to be controlled. In the UK (Hall, 1977; van Dijk, 1991), Australia (Ewart, 1997; Jakubowicz et al., 1994; Thomas \& Green, 2009), Canada (Furniss, 2001; Henry \& Tator, 2002) and USA (Chiricos, Eschholtz, \& Gertz, 2006; Freng, 2007), studies have reported dominant representations of absence, difference, violence, dysfunction and liminality. The marginalisation of indigenous voices in news media implies irrelevance, weakness and lack of agency (Harding, 2005). These newspaper frames reproduce exclusion from significant areas of social life such as commerce (McCreanor et al., 2011), lifestyle, property and computing (Hartley $\&$ McKee, 2000).

Researchers and commentators in Aotearoa have found that Māori are systematically undermined in media constructions of Māori issues and te Tiriti (ACORD, 1983; Cochrane, 1990; Fox, 1992; Phelan, 2009; Phelan \& Shearer, 2009; Saunders, 1996; Spoonley \& Hirsh, 1990; Thompson, 1953; Urutahi Koataata Māori, 2008; RJ Walker, 1990b; R Walker, 2002; Wellington Race Relations Action Group, 1973). Māori commentators are very clear on this point:

there is widespread agreement that the portrayals of Māori ... fail in various ways to provide balanced, fair and accurate reporting. (Raerino, quoted in Haami, 2008, p. 24)

Māori news made up only 1 percent of news in two capital city dailies between 1975 and 1989 (Dawson, 1991) and averaged 6.3 percent between 
1985 and 1994 in four broadcast media outlets (McGregor \& Comrie, 1995). On state broadcaster TVNZ, Māori news in prime time dropped from 3 percent in $2000,{ }^{4}$ to 1.6 percent in 2003 ; in the same years on commercial station TV3 it dropped from 1.2 percent to nil (Comrie \& Fountaine, 2005a).

Newspaper and television news items have been found to be persistently structured from within a Pākehā cultural paradigm (Abel, 2010b; Loto et al., 2006; A. Moewaka Barnes et al., 2005; Rankine et al., 2008). In items about Māori land or resources, Māori practices such as kaitiakitanga ${ }^{5}$ were rarely mentioned and when articles talked about New Zealanders or the public in the context of a Māori resource, the audience they were addressing typically excluded Māori (A. Moewaka Barnes et al., 2005; Phelan, 2006; Stuart, 2005).

Contributing to this marginalisation is the composition of the workforce. Māori were under-represented among reporters, subeditors and editors in 2006, making up 6 percent (Hollings, 2007) of this group. Matheson (2007) found that the 'interpretative resources' of Māori affairs journalists (most of whom were non-Māori) were 'not developed enough to do much about Aotearoa New Zealand journalism's failures in covering Māori politics and culture' (p.102).

The marginalising of Māori presence and worldviews has focussed Māori attention on establishing separate Māori or iwi broadcast media and magazines. Māori broadcast media have been found to provide a much greater diversity of Māori voices than mass news programmes, and give them much more time to speak (Abel, 2010a; Adds et al., 2005; Te Awa, 1996).

Media researchers recognise that the construction of news is embedded in the 'social and cultural relations that develop between journalists and their sources' (Ericson, Baranek, \& Chan, 1989, p. 377). As Gans has argued, 'those who lack power are ... generally not sought out until their activities produce social or moral disorder news' (2004, p. 81).

Research demonstrates that this process continues (Ericson, Baranek and Chan, 1989; Hall, Critcher, Jefferson, Clarke, \& Roberts, 1978; Meadows, 2001; Soloski, 1989; Tuchman, 1978; Venables, 2008). Men usually make up a substantial majority of sources (Brown, Bybee, Wearden, \& Straughan, 1987; Luebke, 1992; McGrath, 1993; McGregor \& Comrie, 1995) with women averaging just 30 percent (Zoch \& VanSlyke Turk, 1998).

Some studies found a dearth of indigenous sources in stories about indigenous issues (Rankine \& McCreanor, 2004, Royal Commission on Aboriginal Peoples, 1996, Scott, 2006). Barclay and Liu (2003, p.9) conclude: 'that it 
is virtually impossible for Māori interests to gain equal voice in the media according to their Treaty partner status'.

There are a few exceptions to this strong pattern. For example Adds et al. (2005) found that Māori speakers were given a higher proportion of speaking time ( 60 pecent on average) than Pākehā (40 percent) on four television news programmes during the 2003 debate about ownership of the foreshore and seabed.

\section{Method}

Our content analyses provide empirical data about the level of coverage, topics and sources in a representative sample of newspaper items about Māori issues and te Tiriti. Constructed weeks mitigated the impact of specific issues during the collection period, and created a broad picture of print news items about Māori. We aimed to gather a snapshot across all newspapers, from local weeklies to big daily papers, of items that were substantially about issues involving Māori, rather than all items that mentioned Māori in passing. We discuss differences between constructions of Māori by small weekly and large daily papers elsewhere (Rankine et al., 2011). We did not control for repetition from sources such as NZPA or stablemate papers, as this would distort the snapshot.

Where methods were similar, results from 2007/2008 (called 2008 for clarity) are compared with our 2004 and 2007 pilot studies. The 2004 pilot study analysed 260 Māori stories collected over one constructed week and one consecutive week, oversampling daily newspapers (A. Moewaka Barnes et al., 2005). Source roles were not coded for this study. The 2007 study analysed 740 randomly selected Māori items published over two constructed weeks in February and March (Rankine et al., 2008). Sources were analysed in only a subset of 254 of the 2007 items on the topics of the Treaty, Waitangi Day, and Māori control of resources, so statistical comparisons are confined to the 2008 and 2004 samples.

\section{Sampling}

In the current project, 21 sampling days were made up from prospective random selections of three of each day of the week between 1 November 2007 and 30 April 2008, to make three constructed weeks (Lacy, Riffe, Stoddard, Martin, \& Chang, 2001).

Print data was collected by Chong Newztel-Media Watch, a professional 
clipping service working to a set of 15 keywords or phrases: constitutional change, disparities (between Māori and mainstream), foreshore and seabed, hapū, iwi, land rights, Māori, Māori development, Māori health, Māori Pākehā relations, sovereignty, te Tiriti o Waitangi, Treaty of Waitangi, Waitangi Tribunal and whānau. Apart from the word Māori on its own, the same set of keywords was used in our two pilot studies.

Items were gathered from more than 120 New Zealand newspapers and some magazines; only items from newspapers published at least weekly were included, resulting in a raw data set of 1,621 items.

We identified stories with a significant focus on Māori issues, te Tiriti and Māori-Pākehā relations, and excluded those where Māori interests were incidental, and non-news items such as letters to the editor. We believe these issues are equally relevant to all; however, like journalists, we have called these items Māori stories.

Two of the researchers read the corpus separately for a first cut of inclusions, exclusions and debateable items, before the selections were discussed and finalised. This resulted in a final database of 858 newspaper items.

\section{Sampling errors}

To check the efficiency of this sampling method, two researchers hand counted articles that fit our criteria for Māori stories in all issues of Auckland paper the New Zealand Herald (NZH) and Wellington's Dominion Post for the three constructed weeks. These papers carried the second and fourth highest number of items respectively of all the publications in our sample. The hand count found seven items that contained keywords but were not included in the raw sample of 1,621 items that Chong's provided, which contained 179 items from the $\mathrm{NZH}$ and the Dominion Post. This gave an error rate of just under four percent. We have been unable to find published figures about acceptable error rates for this sampling system, but we believe this level of undersampling would not have significantly influenced our analyses.

\section{Coding}

Items were coded for the page number and publication in which they appeared, whether daily or non-daily, the author, and the type of items. Items were then assigned to one of 16 topics: Arts, Business, Crime, Education, Fisheries, Foreshore and seabed, Health, Land, Māori/Pākehā relations, Military, Political representation, Religion, Sport, Social issues, Tikanga (items about Māori customs and procedures) and Treaty of Waitangi. Two Māori 
researchers read the corpus to decide on items for the tikanga category; other items were allocated to topics by two Pākehā researchers reading the corpus separately, with discussion by the full team where there was any disagreement. This ensured stable and consensually agreed coding.

\section{Sources}

Items were coded for the number of people cited or quoted, whether sources were unavailable for comment, the ethnicity, role, gender and order of sources, and the number of sentences per source. Where the ethnicity, role or gender of a source was not on the public record, sources were contacted by phone. Up to 20 phone calls were made before some sources could be contacted. Where sources were unavailable, occasionally a close relative or work colleague was able to supply this information.

We used a framework based on the Treaty of Waitangi to categorise sources, starting with the signatories - representatives of iwi/hapū and government, which included government Members of Parliament (MPs), department spokespeople, local body politicians, and police or armed forces spokespeople. Non-governmental organisations (NGOs) were categorised as either Māori or tauiwi (non-Māori). However, non-government MPs made up such a large block of sources that they were categorised separately. The last category was unaffiliated individuals. Each item was coded for all these variables in an Access database, and results outputted into Excel spreadsheets.

\section{Results}

Story counts

The 858 Māori stories from 2008 were published in 120 different local, regional, and national newspapers. The great majority of the Māori stories (723) were news articles. The four other categories - opinion columns (68), feature articles (38), reviews (16) and editorials (13) — together made up 16 percent of items. These proportions were very similar in the 2007 pilot sample from a constructed fortnight (see Table 1).

Daily newspapers contributed 490 items ( 57 percent) while 368 (43 percent) were from non-daily papers. For the 25 dailies this represents an average of just over one article per collection day and less than one for non-daily papers. We estimated that Māori stories averaged 2.6 percent of the total in non-daily papers in the Suburban Newspapers stable (Rankine et al., 2011). While the number of publications in the constructed fortnight of the 2007 
Table 1: Comparison of news item type

\begin{tabular}{|l|c|c|}
\hline Type of item & 2008 (percent) & 2007 pilot (percent) \\
\hline News articles & 84 & 85 \\
\hline Opinion columns & 8 & 6 \\
\hline Feature articles & 4 & 3 \\
\hline Reviews & 2 & 2 \\
\hline Editorials & 3 & 3 \\
\hline & 101 & 99 \\
\hline
\end{tabular}

pilot study was very similar (118), its ratio of daily papers (73 percent) to non-daily papers (27 percent) was significantly higher.

The 10 papers with the highest number of Māori stories accounted for 38 percent of the sample but the highest rating paper averaged less than three items per collection day; 28 newspapers published only one Māori story over the three weeks, and 25 non-daily papers did not appear in the sample.

The distribution of Māori news items across newspapers was broadly similar in 2004 and 2008 (see Table 2).

\begin{tabular}{|l|c|c|c|}
\hline Table 2: Placement of Māori news items in newspapers \\
\hline Placement of item & 2008 (percent) & 2007 pilot (percent) & 2004 pilot (percent) \\
\hline Front page & 8 & 11 & 10 \\
\hline Newspages 2 to 5 & 40 & 56 & 58 \\
\hline News pages 6 to 10 & 21 & 18 & 16 \\
\hline News pages 11 onwards & 23 & 13 & 10 \\
\hline Non-news pages & 8 & 2 & 7 \\
\hline & 100 & 100 & 101 \\
\hline
\end{tabular}

\section{Topics}

The distribution of topics was very different from the 2004 sample. In 2008, arts, crime and education were most common, while in 2004 political representation, the Treaty and health were the most common issues.

Four of the six most repeated stories in the sample - coverage of the raids on so-called 'Māori terrorists' (20 items); Waitangi day (16); fraud in Māori organisations (15) and the conviction of a Māori teacher for sexual assault (14) — focused on Māori as a threat or criminal (see Table 3). 


\section{Table 3: Topics in 2008}

\begin{tabular}{|l|c|c|}
\hline Topic & Number of items & Percentage \\
\hline Arts & 107 & 17 \\
\hline Crime & 100 & 12 \\
\hline Education & 85 & 10 \\
\hline Social issues & 81 & 9 \\
\hline Māori/Pākehā relations & 80 & 9 \\
\hline Health & 60 & 7 \\
\hline Political representations & 53 & 6 \\
\hline Land & 52 & 6 \\
\hline Treaty of Waitangi & 52 & 6 \\
\hline Sport & 50 & 6 \\
\hline Tikanga & 37 & 3 \\
\hline Business & 25 & 2 \\
\hline Military & 18 & 1 \\
\hline Fisheries & 11 & 0.6 \\
\hline Religion & 5 & 0.2 \\
\hline Foreshore and seabed & 2 & 99 \\
\hline Totals & 858 & \\
\hline
\end{tabular}

\section{Sources}

In the 2008 sample, 151 Māori stories (18 percent) listed no sources for their information. This is three times the proportion of such items in 2007 (6 percent) and 2004 (5 percent). The ten papers in 2008 with the most un-sourced items, totalling 60, were all dailies. Arts, Crime and Education topics were prevalent among stories with no sources (totalling 51 percent, $\mathrm{p}<.05$ ). The other 707 stories used 1,449 sources, 1,005 of which were unique, an average of 1.69 sources per item. The 2004 sample average was significantly higher-2.7 $(\mathrm{p}<.05)$ - consistent with Venables' (2008) average range from 2.2 to 3.1 in 2001 .

Almost half the stories with sources $(349,49$ percent) used only one, a significant increase $(\mathrm{p}<.05)$ over the proportion of single-source stories in 2004 (39 percent). A smaller proportion ( 23 percent) was observed in the 2007 subset. In 2008, two sources were used in 160 items (23 percent of those with sources), 102 items (14 percent) used three sources, and smaller 
numbers used more. A feature summarising 'race relations' in 2007 used the most sources- 11 .

\section{Ethnicity}

In 2008, 16 sources were reported as declining or being unavailable for comment. Of these, nine were Māori, four were Pākehā and the ethnicity of three Government sources was unidentified. In the earlier studies Māori were also the majority of the sources declining or unavailable: 2007 (8 of 15) and 2004 (27 of 29).

For this study, opinion columnists were counted as sources of their own column. Columns were evenly split between daily and non-daily papers (34 each). The writer's ethnicity was unknown for two of the 68 columns, one was written by Māori and Pākehā school students and the other columnist was Tauiwi. Of the remaining 64, Māori writers contributed 39 (61 percent) and Pākehā 25 (39 percent), compared to 50 percent each in the 2007 subset. However, dailies carried significantly more columns by Pākehā (21, 62 pecent of daily columns) and the smaller circulation non-dailies carried significantly more Māori opinion (28, 82\%, $\mathrm{p}<.05)$. Thirteen editorials commented on Māori or Treaty issues; we were not aware of any Māori editors of city or provincial newspapers in 2008.

The proportion of Pākehā sources in the 2008 sample was more similar to the 2004 pilot study, where sources were also counted for all Māori stories, than to the 2007 resources subset (see Table 4).

Table 4: Comparison of source ethnicity
\begin{tabular}{|l|c|c|c|}
\hline Source ethnicity & 2008 (percent) & 2007 (percent) & 2004 (percent) \\
\hline Pākehā & 42 & 35 & 45 \\
\hline Māori & 41 & 45 & 37 \\
\hline Other ethnicity & 5 & 5 & 1 \\
\hline Māori/Pākehā & 1 & 3 & 2 \\
\hline Unidentified & 10 & 11 & 15 \\
\hline Total & 99 & 99 & 100 \\
\hline
\end{tabular}

Māori made up a greater proportion of the 710 first sources in stories (334, 47 percent) than Pākehā (263, 37 percent). Māori were quoted earlier in stories, a mean of the ninth sentence, compared to the Pākehā mean of the eleventh sentence. This order is similar to the 2007 subset, where Māori 
were quoted at a mean of the eleventh sentence and Pākehā at a mean of the 14th sentence. However, in the 2004 representative sample, Pākehā men were quoted earlier at a mean of the fourth sentence, with Māori first quoted at a mean of the seventh sentence and Pākehā women at a mean of the 12th sentence (see Table 5).

\begin{tabular}{|l|c|c|c|c|c|c|}
\hline Table 5: Role of sources \\
\hline Source role & \multicolumn{3}{|c|}{2008} & \multicolumn{2}{c|}{2007 Treaty and resource items } \\
\hline & Number & Percent & $\begin{array}{l}\text { Speaking } \\
\text { order (mean } \\
\text { sentence) }\end{array}$ & Number & Percent & $\begin{array}{l}\text { Speaking } \\
\text { order (mean } \\
\text { sentence) }\end{array}$ \\
\hline Tauiwi NGOs & 375 & 26 & 10 & 106 & 14 & - \\
\hline $\begin{array}{l}\text { Government } \\
\text { representatives }\end{array}$ & 339 & 23 & 10 & 241 & 31 & 11 \\
\hline $\begin{array}{l}\text { Unaffiliated } \\
\text { individuals }\end{array}$ & 334 & 23 & 12 & 86 & 11 & - \\
\hline Māori NGOs & 197 & 14 & 8 & 27 & 3 & - \\
\hline $\begin{array}{l}\text { Non-government } \\
\text { MPs }\end{array}$ & 129 & 9 & 11 & 129 & 17 & - \\
\hline $\begin{array}{l}\text { Iwi/hapū spokes- } \\
\text { people }\end{array}$ & 70 & 5 & 10 & 175 & 23 & 12 \\
\hline Unidentified & 5 & 0.3 & 10 & - & 0 & - \\
\hline Total & 52 & 100.3 & & & 99 & \\
\hline
\end{tabular}

In 2008, Māori were also quoted for significantly more sentences $(3,986,50$ percent, $\mathrm{p}<.05)$ compared to Pākehā $(2,947,37$ percent). In 2007 resources items, Pākehā were quoted for slightly longer (five sentences) than Māori (four).

Role

Tauiwi (non-Māori) non-government organisations (NGOs) made up the biggest group of sources in the current study $(26 \%)$, and contributed a significantly higher proportion of total sentences ( 31 percent) than they did of sources $(\mathrm{p}<.05)($ see Table 5). Government spokespeople, however, spoke for a significantly lower proportion of total sentences (14 percent) than their proportion of sources ( 23 percent, $\mathrm{p}<.05$ ). Iwi and hapu representatives made up only one in ten Māori sources (see Table 6). 
Table 6: Role of Mãori sources in 2008

\begin{tabular}{|l|c|c|c|c|c|c|c|c|}
\hline Role & $\begin{array}{c}\text { Māori } \\
\text { NGO }\end{array}$ & $\begin{array}{c}\text { Indivi- } \\
\text { duals }\end{array}$ & $\begin{array}{c}\text { Other } \\
\text { MPs }\end{array}$ & Iwi & $\begin{array}{c}\text { Tauiwi } \\
\text { NGO }\end{array}$ & $\begin{array}{c}\text { Govern- } \\
\text { ment }\end{array}$ & $\begin{array}{c}\text { Net } \\
\text { stated }\end{array}$ & Totals \\
\hline Number & 176 & 136 & 89 & 69 & 64 & 59 & 1 & 594 \\
\hline Percentage & 30 & 23 & 15 & 12 & 11 & 10 & 0 & 100 \\
\hline
\end{tabular}

Those Māori who were quoted first were most likely to represent non-Māori NGOs, the government, or to speak as individuals. While Māori Party MPs made up four of the six most commonly quoted Māori sources, non-government MPs as a group, made up only six percent of first sources.

\section{Gender}

Male sources outnumbered female sources by more than two to one in all three samples. Media use of male sources was consistent: 63 percent in 2008, 62 percent in 2007 and 64 percent in 2004 . Female sources increased slightly over the three samples: 21 percent in 2004, 26 percent in 2007 and 30 percent in 2008. In 2008, the gender of 6 percent of sources could not be identified. Male sources were also quoted for longer $(5,402$ sentences, 68 percent of the total). Women spoke 29 percent of the total sentences (Table 7).

\section{Table 7: Ethnicity and gender of sources}

\begin{tabular}{|l|c|c|c|}
\hline Ethnicity and gender & 2008 (percent) & 2007 (percent) & 2004 (percent) \\
\hline Pākehā men & 30 & 26 & 37 \\
\hline Māori men & 26 & 38 & 25 \\
\hline Pākehā women & 12 & 8 & 8 \\
\hline Māori women & 14 & 14 & 12 \\
\hline
\end{tabular}

Pākehā men made up the biggest group by gender and ethnicity in the 2008 and the 2004 representative samples. Women made up a higher proportion of Māori sources in 2008 (35 percent), 2007 (32 percent) and 2004 (32 percent) than they did of Pākehā sources ( 29 percent, 24 percent and 18 percent respectively).

\section{Discussion}

Our analysis shows coverage of Māori stories to be at a very low level in newspapers throughout the country-around one story per paper per day which even in non-daily papers amounted to less than 3 percent of total stories, 
meaning that Māori citizens rarely see themselves reflected in this medium. Our analysis of television news (Nairn et al., 2012) provides some comparison. The combined bulletins from TV One, TV Three and Prime News ran a total of 17 distinct Māori stories over the three weeks while Māori Television Service carried over 250 items, showing the depth of untold Māori stories.

Content analysis does not allow us to explore the thematic dimensions of the coverage within topics but our thematic and discourse analyses show that as a result of the hegemonic framework within which news is produced the preponderance of the sample represented Māori in a negative light (A. Moewaka Barnes et al., 2012). For example, because of the inequalities referred to above, coverage in topics like Education, Health, and Business focused on under-achievement or sickness (Rankine et al., 2008). Other areas such as Land, Treaty, Political Representation and Māori/Pākehā relations are inherently oriented to social tensions. Even in apparently neutral areas such as Arts, Sport and Social Issues (McCreanor et al., 2010), much of the coverage assimilates Māori as New Zealanders or presents them as succeeding through special advantages like affirmative action programmes. Only three percent (25) of the items focused on business and the Māori economy, a quarter of the numbers reporting Māori Crime. Coverage of the Māori economy was a smaller proportion than found in the 2004 sample ( 6 percent) and the 2007 sample (4 percent), although the number of Māori entrepreneurs increased by 23 percent from 2001 and 2006 (Te Puni Kokiri, 2010), and the 2007 sample included a feature on the significance of the Māori business sector (Edlin, 2007). This is consistent with the lack of items about the Aboriginal economy in Australia (Roberts, 2007).

While controversy is a news staple, in these stories the controversy is associated with Māori, while Pākehā are ethnically unmarked in these and the vast majority of all news stories. Pākehā were just as likely to be quoted as Māori; given the diversity of viewpoints among Māori, it is unnecessary for journalists seeking balancing comment to go so often to Pākehā spokespeople.

Our analysis indicates a decline in the number of sources between 2004 and 2008, and a significant increase in unsourced Māori stories. As our efforts to identify source ethnicity and gender were exhaustive, the ten percent of sources whose ethnicity remained unidentified is probably close to the achievable minimum, given media use of sources such as reports and unidentified vox pops. 
This was the first representative sample where sources were analysed by role. It indicates that media prefer speakers who are accessible or have status within Pākehā structures, and rarely recognise any right of iwi and hapū to comment on Treaty and resources issues. Stories using iwi and hapu sources are more likely to include Māori concepts such as kaitiangatanga and tino rangatiratanga (A. Moewaka Barnes et al., 2005).

Māori who were elected representatives or spokespersons for other Government agencies were quoted at three times the rate of iwi representatives. This is consistent with the multicultural framework noted by Barclay and Liu (2003), and with ongoing newspaper discourses that undermine or marginalise te Tiriti o Waitangi (A. Moewaka Barnes et al., 2005; Rankine et al., 2008), with the 2004 pilot study and other content analyses of representative samples of New Zealand media (Comrie \& Fountaine, 2005b; McGregor \& Comrie, 2002). The only studies that found a higher proportion of Māori speakers were those that limited themselves to single issues such as the foreshore and seabed (Adds et al., 2005) and similar core Māori resources (Rankine et al., 2008).

There is no consistent pattern in length of quotes or position in stories by ethnicity over our three studies. This is an area in which discourse and thematic analyses can be useful, as an article may be framed in a certain way before the first speaker is quoted.

While Māori opinion made up more than half the total opinion columns in this study, they were mainly in much smaller circulation publications. Pākehā viewpoints about Māori issues were available to a much greater readership.

While the low proportion of female sources is consistent with international studies, the proportion of spokeswomen among Māori sources is higher than among Pākehā. Despite the presence of Pākehā women among the senior government decision-makers about Māori issues over the sample periods, this analysis indicates that more Māori than Pākehā women may be filling spokesperson roles.

\section{Limitation}

Our study is limited by the use of keywords to select the corpus from the total coverage. We will have missed items about particular individuals - for example, celebrities, politicians or offenders wanted by the police-who have Māori names or are widely recognised as Māori but where the articles do not touch on issues that the keywords were designed to include. However, even if this problem were to undercount Māori stories by a factor of two, the 
rates of coverage would still be very low and our fundamental conclusions remain.

\section{Conclusion}

Our quantitative and qualitative research suggests that mass print media contribute to the marginalisation of indigenous issues and the ongoing maintenance of problematized social relations. The analyses demonstrate an effective marginalisation of Māori stories, and of Māori voices on issues concerning Māori. Coupled with negative or contentious orientation of coverage identified in qualitative analyses (A. Moewaka Barnes et al., 2012), this creates or maintains Māori as marginal, problematic or 'other' in their land of origin. Our findings raise concerns about the role that mass media plays in reinforcing dominant norms but also point to potential for change. Māori Television shows that news can be and is told differently compared to the mass channels without any sacrifice of accuracy, immediacy or audience interest. More study of the processes involved could suggest ways in which newspapers could achieve more equitable coverage.

\section{Notes}

1. We use the term mass media to denote the majority-controlled media as distinct from indigenous media such as Māori radio and television services that operate in Aotearoa.

2. 'By Māori, for Māori’ approaches, after Smith (1999).

3. People of the land.

4. TVNZ's charter, implemented in 2003, included a commitment to quality news and current affairs, and specified the participation of Māori and a significant Māori voice but was abolished in 2010 .

5. Loosely guardianship, but entailing a reciprocity of rights and responsiblities between land and peoples.

\section{References}

Abel, S. (2010a, August 3). A question of balance. The New Zealand Herald. Retrieved on 21 March 2014, from www.nzherald.co.nz/opinion/news/article. cfm?c id=466\&objectid $=10663343$

Abel, S. (2010b). A question of balance. Auckland University 'The end(s) of journalism?’ Winter Lecture series. Retrieved on 16 February 2011, from www.auckland. ac.nz/winter

ACORD. (1983). Before the Broadcasting Tribunal. Auckland. 
Adds, P., Bennett, M., Hall, M., Kernot, B., Russell, M., \& Walker, T. (2005). The portrayal of Māori and Te Ao Māori in broadcasting: The foreshore and seabed issue. Wellington: Broadcasting Standards Authority.

Ballara, A. (1986). Proud to be white: A survey of racial prejudice in New Zealand. Auckland: Heinemann.

Barclay, K., \& Liu, J. (2003). Who gets voice? (Re)presentation of bicultural relations in New Zealand print media. New Zealand Journal of Psychology, 32, 3-12.

Brown, J., Bybee, C., Wearden, S., \& Straughan, D. (1987). Invisible power: Newspapers news sources and the limits of diversity. Journalism Quarterly, 64, 45-54.

Chiricos, T., Eschholtz, S., \& Gertz, M. (2006). Crime, news and fear of crime: Towards an identification of audience effects. In G. Potter \& V. Kappler (Eds.), Constructing crime: Perspectives on making news and social problems. Illinois: Waveland Press.

Cochrane, J. (1990). Media treatment of Māori issues. Sites, 21, 5-29.

Colvin, G. (2010). The soliloquy of whiteness: Colonial discourse and New Zealand's settler press 1839-1873. An unpublished thesis submitted in partial fulfilment of the requirements for the degree of Doctor of Philosophy in Journalism, University of Canterbury.

Comrie, M., \& Fountaine, S. (2005a). Knowing through news: The information content of TVNZ news. Paper presented at the Third International Conference on New Directions in the Humanities, University of Cambridge, 2-5 August.

Comrie, M., \& Fountaine, S. (2005b). Who is making the news? Paper presented at the ANZCA 2005 Conference: Communication at Work-Showcasing Communication Scholarship, University of Canterbury, 4-7 July.

Connell, R. (2007). Southern theory: The global dynamics of knowledge in social science. Cambridge: Polity Press.

Davis, A. (2002). Public relations democracy: Public relations, politics and the mass media in Britain. Manchester: Manchester University Press.

Dawson, D. (1991). Mãori in the news. Unpublished Masters thesis, Victoria University of Wellington.

Edlin, B. (2007, 14 March). Maori business: The challenge, Independent Financial Review, p. 12.

Ericson, R., Baranek, P., \& Chan, J. (Eds.). (1989). Negotiating control: A study of news sources. Open University Press: Milton Keynes.

Ewart, J. (1997). The scabsuckers: Regional journalists' representation of indigenous Australians. Asia Pacific Media Educator, 3, 108-117.

Fox, D. (1992). The Māori perception of the news. In J. McGregor \& M. Comrie (Eds.), Whose News? Palmerston North: Dunmore Press.

Freng, A. (2007). American Indians in the news: A media portrayal in crime articles. American Indian Culture and Research Journal, 31(1), 21-37.

Furniss, E. (2001). Aboriginal justice, the media, and the symbolic management of Aboriginal/Euro-Canadian relations. American Indian Culture and Research Journal, 25(2), 1-36.

Gans, H. (2004). Deciding what's news: A study of CBS Evening News, NBC Nightly

PACIFIC JOURNALISM REVIEW 20 (1) 2014229 
News, Newsweek and Time. Illinois: Northwestern University Press.

Gregory, M., Borell, B., McCreanor, T., Moewaka Barnes, A., Nairn, R., Rankine, J., . . Kaiwai, H. (2011). Reading news about Māori: Responses from non-Māori audiences. AlterNative, 7(1), 51-64.

Haami, B. (2008). Urutahi Koataata Māori/ Working with Māori in Film and Television. Auckland: Renee Mark.

Hall, S. (1977). Culture, the media and the ideological effect. In J. Curran, M. Gurevitch \& J. Woollacott (Eds.), Mass communication and society. London: Arnold.

Hall, S., Critcher, C., Jefferson, T., Clarke, J., \& Roberts, B. (1978). Policing the crisis. London: Macmillan.

Harding, R. (2005). The media, Aboriginal people and common sense. Canadian Journal of Native Studies, 25(1), 311-335.

Hartley, J., \& McKee, A. (2000). The indigenous public sphere-the reporting and reception of aboriginal issues in the Australian media. Oxford: Oxford University Press.

Henry, F., \& Tator, C. (2002). Discourses of domination: Racial bias in the Canadian English-language press. Toronto: University of Toronto Press.

Hollings, J. (2007). Still European and female, but older: Profiling the New Zealand journalist. Pacific Journalism Review, 13(1), 183-193.

Jakubowicz, A., Goodall, H., Martin, J., Mitchell, T., Randall, L., \& Seneviratne, K. (1994). Racism, ethnicity and the media. St Leonards: Allen and Unwin.

Lacy, S., Riffe, D., Stoddard, S., Martin, H., \& Chang, K.-K. (2001). Sample size for newspaper content analysis in multi-year studies. Journalism and Mass Communication Quarterly, 78(4), 836-845.

Loto, R., Hodgetts, D., Chamberlain, K., Nikora, L., Karapu, L., \& Barnett, A. (2006). Pasifika in the news: The portrayal of Pacific peoples in the New Zealand press. Journal of Community and Applied Social Psychology, 16, 100-118.

Luebke, B. (1992). Commentary: No more content analyses. Newspaper Research Journal, 13, 1-2.

Maori Television (2010) Mai i Aotearoa ki te ao whänui. Pürongo-ä-tau Annual Report 2010. Auckland: MTS.

Matheson, D. (2007). The interpretative resources of Aotearoa New Zealand journalists reporting on Maori. New Zealand Journal of Media Studies, 10(2), 91-105.

McCreanor, T., McManus, A.-L., Moewaka Barnes, A., Rankine, J., Borell, B., \& Nairn, R. (2011). Maori business news in the mass media. Sites: New Series, $8(2), 32-56$.

McCreanor, T., Rankine, J., Moewaka Barnes, A., Borell, B., Nairn, R., Gregory, M., \& Kaiwai, H. (2010). Māori sport and Māori in sport: Mass media representations and pākehā discourse. Alternative, 6(3), 235-247.

McGrath, K. (1993). Women and newspapers. Newspaper Research Journal, 14, 95-110.

McGregor, J. (2002). Crime news: The cutting edge. In J. McGregor \& M. Comrie (Eds.), What's news: Reclaiming journalism in New Zealand (pp. 81-95). Palmerston North: Dunmore Press. 
McGregor, J., \& Comrie, M. (1995). Balance and fairness in broadcasting news 1985-1994. Palmerston North: Massey University.

McGregor, J., \& Comrie, M. (Eds.). (2002). What's news? Reclaiming journalism in New Zealand. Palmerston North: Dunmore Press.

Meadows, M. (2001). Voices in the wilderness: Images of aboriginal people in the Australian media. Greenwood Press: Westport.

Ministry of Social Development. (2010). The social report 2010. Retrieved on 2 March 2011, from www.socialreport.msd.govt.nz/introduction/index.html

Moewaka Barnes, A. (2011). Nga kai para i te kahikatoa: Māori pioneers offilmmaking. Unpublished PhD thesis, University of Auckland, Auckland.

Moewaka Barnes, A., Borell, B., Taiapa, K., Rankine, J., Nairn, R., \& McCreanor, T. (2012). Anti-Māori themes in New Zealand journalism: Toward alternative practice. Pacific Journalism Review, 18(1), 195-216.

Moewaka Barnes, A., Gregory, M., McCreanor, T., Nairn, R., Pega, F., \& Rankine, J. (2005). Media and Te Tiriti o Waitangi 2004. Auckland: Kupu Taea.

Moewaka Barnes, H. (2000). Kaupapa Māori: Explaining the ordinary. Pacific Health Dialog, 7, 13-16.

Mutu, M. (2011). The state of Māori rights. Wellington: Huia Publishers.

Nairn, R., McCreanor, T., Moewaka Barnes, A., Borell, B., Rankine, J., \& Gregory, A. (2012). 'Māori news is bad news': That's certainly so on television. MAI Journal, 1(1), 38-49.

Nairn, R., Moewaka Barnes, A., Rankine, J., Borell, B., Abel, S., \& McCreanor, T. (2011). Mass media in Aotearoa: An obstacle to cultural competence. New Zealand Journal of Psychology, 40(3), 168-175.

Ngugi, T. (1986). Decolonising the mind: The politics of language in African literature. Portsmouth, NH: Heinemann.

Office of Treaty Settlements. (2013). Claims progress. Retrieved in February 2014, from www.ots.govt.nz/

Phelan, S. (2006). The mediatised antagonism of the New Zealand/Aotearoa 'foreshore and seabed' conflict. Retrieved on 10 October 2007, from www.psa.ac.uk/2006/ pps/Phelan.pdf

Phelan, S. (2009). The newspaper as political antagonist: Editorial discourse and the othering of Māori perspectives on the foreshore and seabed conflict. Journalism, 10(2), 217-237.

Phelan, S., \& Shearer, F. (2009). The 'Radical', the 'Activist' and hegemonic newspaper articulation of the Aotearoa New Zealand foreshore and seabed conflict. Journalism Studies, 10(2), 220-237.

Pihama, L., Cram, F., \& Walker, S. (2002). Creating methodological space: A literature review of kaupapa Māori research. Canadian Journal of Native Education, 26, 30-43.

Rankine, J., \& McCreanor, T. (2004). Colonial coverage: Media reporting of a bicultural health research partnership. Journalism, 5(1), 5-29.

Rankine, J., Moewaka Barnes, A., Borell, B., McCreanor, T., Nairn, R., \& Gregory, A. (2011). Suburban Newspapers' reporting of Māori news. Pacific Journalism Review, 17(2), 50-71. 
Rankine, J., Nairn, R., Moewaka Barnes, A., Gregory, M., Kaiwai, H., Borell, B., \& McCreanor, T. (2008). Media \& Te Tiriti Waitangi 2007. Tamaki Makaurau/ Auckland: Kupu Taea: Media and Te Tiriti Project.

Reid, P., \& Robson, R. (2007). Understanding health inequities. In Robson, B. \& Harris, R. (Eds.), Hauora: Māori standards of health IV. A study of the years 20002005 (pp. 3-10). Wellington: Te Ropu Rangahau Hauora a Eru Pomare.

Roberts, J. (2007). Analysis of the representation of Indigenous Australians in mainstream print media: An exploration centred on the social determinants of health. Unpublished Bachelor of Health Science (Hons) Thesis, La Trobe University, Australia.

Robson, B., \& Harris, R. (Eds.). (2007). Hauora: Māori standards of health IV. A study of the years 2000-2005. Wellington: Te Rōpū Rangahau Hauora a Eru Pōmare.

Royal Commission on Aboriginal Peoples. (1996). Final Report. Vol. 4-Public Education: Building Awareness and Understanding. Ottawa: Canada Communications Group.

Saunders, J. (1996). Skin deep: The news media's failure to cover Māori politics. In J. McGregor \& M. Comrie (Eds.), Dangerous democracy: New media politics in New Zealand. Palmerston North: Dunmore Press.

Scott, L. (2006). Negative Exposure: A snapshot of ATSIC in Australia's mainstream print media. Melbourne Journal of Politics, 31, 75-90.

Smith, L. (1999). Decolonizing methodologies: Research and indigenous peoples. London: Zed.

Soloski, J. (1989). Sources and channels of local news. Journalism Quarterly, 6, 864-870.

Spoonley, P., \& Hirsh, W. (1990). Between the lines: Racism and the New Zealand media. Auckland: Heinemann Reed.

Statistics New Zealand (2008). Demographic trends: 2007. Retrieved on 26 August 2011, from www.stats.govt.nz/browse_for_stats/population/estimates_and_projections/demographic-trends-2007.aspx

Statistics New Zealand (2014). 2013 Census QuickStats about Māori, from www. stats.govt.nz/Census/2013-census/profile-and-summary-reports/quickstats-aboutmāori-english/population.aspx

Stuart, I. (2005). The Māori public sphere. Pacific Journalism Review, 11(1), 13-25.

Te Awa, J. (1996). Mana news: A case study. Sites, 33, 168-175.

Te Mangai Paho. (2011). Tuhia te ha o te reo Māori ki te rangi. Retrieved on 26 August 2011, from www.tmp.govt.nz/about.html

Te Puni Kokiri. (2010). Tirohanga ohanga mo te Moana ā Toi: Māori entrepreneurship in Te Moana a Toi and New Zealand for 2001 and 2006. Wellington: Te Puni Kokiri.

Te Puni Kokiri. (2011). Two years on: Māori Economic Taskforce. Kokiri, 22. Retrieved from www.tpk.govt.nz/en/in-print/kokiri/kokiri-22-2011/two-yearsonmaori-economic-taskforce/

Thomas, V., \& Green, R. (2009). Family violence reporting: Supporting the vulnerable or reinforcing their vulnerability? Asia Pacific Media Educator, 19, 55-70. 
Thompson, R. (1953). Māori affairs and the New Zealand press. Journal of the Polynesian Society, 62(4), 366-383.

Tuchman, G. (1978). Making news: A study in the construction of reality. New York: Free Press.

Urutahi Koataata Māori. (2008). Working with Māori in film and television. Auckland: Ngā Aho Whakaari.

van Dijk, T. (1991). Racism and the press. London: Routledge.

Venables, D. (2008). Making politics go well down under: Public journalism in New Zealand daily newspapers. Unpublished Masters of Management in Communication Management Massey University.

Waitangi Tribunal. (2011). Homepage. Retrieved on 10 March 2008, from www. waitangitribunal.govt.nz/

Walker, R. (1990a). Ka whawhai tonu matou. Auckland: Penguin.

Walker, R. (1990b). The role of the press in defining Pākehā perceptions of the Māori. In P. Spoonley \& W. Hirsh (Eds.), Between the lines: Racism and the New Zealand media (pp. 37-46). Auckland: Heinemann Reed.

Walker, R. (2002). Māori news is bad news. In J. McGregor \& M. Comrie (Eds.), What's news: Reclaiming journalism in New Zealand. Palmerston North: Dunmore.

Wellington Race Relations Action Group. (1973). Coverage of Māori issues in eight Wellington area provincial dailies. Wellington: WRRAC.

Zoch, L., \& VanSlyke Turk, J. (1998). Women making news: Gender as a variable in source selection and use. Journalism and Mass Communication Quarterly, 75, $762-775$.

Jenny Rankine is a Pākehā researcher interested in media representations in the fields of gender, ethnicity and culture.

Angela Moewaka Barnes is a Māori media researcher studying film and mass media representations of indigenous people.

Tim McCreanor is a Pākehā researcher experienced in qualitative research and discursive methods in the study of culture, equity and justice.

Ray Nairn is a Pākehā research psychologist with interests in media representations and social justice.

Anna-Lyse McManus is a Māori statistician.

Sue Abel is a senior lecturer in film, television and media studies.

Belinda Borell is a Māori social scientist focussing on power, privilege and whiteness within the studies of the health/wellbeing of indigenous people.

Amanda Gregory is a Pākehā qualitative social science researcher interested in social relations, gender, ethnicity, health/wellbeing.

Dr Tim McCreanor, t.n.mccreanor@massey.ac.nz 